\title{
LEPASNYA SEL ENDOTEL DAN VASCULAR ENDOTHELIAL CADHERIN (VE- CADHERIN) PADA HUVECS DENGAN GLUKOSA TINGGI DAN FLUID SHEAR STRESS
}

\author{
Yoyon Arif Martino, Erna Sulistyowati* \\ Fakultas Kedokteran Universitas Islam Malang
}

\begin{abstract}
ABSTRAK
Latar Belakang. Sel endotel melapisi lumen pembuluh darah sehingga menyebabkan paparan langsung aliran darah dan timbul gaya hemodinamik shear stress. Vascular Endothelial (VE) Cadherin merupakan salah satu struktur penghubung antar sel yang berperan mencegah terlepasnya sel endotel dari membran dasar. Paparan glukosa tinggi menyebabkan stress oksidatif sehingga sel endotel mengalami apoptosis dan nekrosis dan terlepas. Penelitian ini bertujuan mempelajari efek paparan glukosa tinggi dan fluid shear stress terhadap morfologi, struktur VE-Cadherin dan densitas sel endotel pada kultur sel endotel HUVECs (Human Vein Endothelial Cells Culture).

Metode Penelitian eksperimental laboratorium dengan metode HUVECs yang dipapar d-glukosa 22 $\mathrm{mM}$ selama 7 hari. Shear stress dibangkitkan dengan alat cone and plate 10 dyne $/ \mathrm{cm}^{2}$ selama $5,8,12$ dan 15 menit. Pulasan VE-Cadherin dengan imunohistokimia. Data dianalisis dengan metode statistik. Signifikan pada $\mathrm{p}<0,05$.

Hasil Shear stress selama 15 menit menyebabkan perubahan bentuk sel endotel menjadi lebih panjang dan inti sel lebih pipih. Paparan glukosa tinggi dan fluid shear stress menyebabkan penurunan skor VECadherin dan densitas sel endotel secara signifikan Penurunan skor VE-Cadherin berpengaruh langsung terhadap penurunan densitas sel endotel.

Kesimpulan. Paparan glukosa tinggi dan fluid shear stress menyebabkan kerusakan struktur VECadherin sehingga terjadi peningkatan apoptosis dan nekrosis sel endotel.

Kata Kunci : Glukosa tinggi, shear stress, VE-Cadherin, densitas sel endotel.

\section{*Korespondensi:}

dr. Erna Sulistyowati, M.kes., Ph.D

Email: dr_erna@unisma.ac.id

Gedung F 1t.2 J1.MT Haryono 193 Malang Jawa Timur kode pos 65146

No telp/fax/handphone:(0341)578920/fax(0341)558958/HP. 085132443018
\end{abstract}

\section{LATAR BELAKANG}

Penyakit kardiovaskuler terutama aterosklerosis merupakan penyebab kematian terbanyak di dunia bahkan di Indonesia sendiri. Data WHO menyebutkan bahwa di negara berkembang termasuk Indonesia penyakit kardiovaskuler ini menjadi penyebab kematian pertama yakni sebesar $37 \%$. Penyakit kardiovaskuler ini didominasi oleh penyakit iskemia (ischemic hearth diseases) yang timbul karena proses aterosklerosis [1].
Komplikasi penyakit kardiovaskuler ini terutama pada penderita diabetes mellitus serta beberapa faktor resiko lain seperti merokok, hipertensi, obesitas, genetik dan beberapa faktor resiko yang lain [2]. Data epidemiologi dari Framingham study dan Multiple Risk Factor Intervention Trial menunjukkan bahwa resiko kematian karena penyakit kardiovaskuler meningkat dua hingga tiga kali lipat pada penderita diabetes. Setelah serangan infark miokard, morbiditas dan mortalitas 
kardiovaskuler meningkat pada penderita diabetes akibat proses aterosklerosis [2].

Aterosklerosis adalah penyakit dimana plak lemak tumbuh pada dinding dalam arteri [3]. Plak mungkin akan berkembang pada suatu tempat sehingga menyumbat pembuluh darah mengakibatkan penurunan aliran darah, pembentukan bekuan darah, serangan jantung dan stroke. Sel endotel yang terdapat di dalam dinding pembuluh darah berperan di dalam aterosklerosis. Sel endotel pembuluh darah berada antara dinding pembuluh dan darah, maka endotel secara langsung terkena oleh gaya hemodinamik. Gaya hemodinamik seperti shear stress juga berperan dalam proses terbentuknya aterosklerosis terutama bila shear stress-nya oscillatory yakni berkekuatan rendah dan kondisinya berubah-ubah [4].

Sel endotel secara normal bersifat non trombotik sehingga memperkecil kemungkinan terbentuk plak aterosklerosis [5]. Shear stress secara fisiologis bersifat vaskuloprotektif dalam hubungannya dengan sifat antitrombotik [6]. Namun bila kondisinya rendah dan berubah-ubah akan bersifat patologis yang mempermudah terbentuk aterosklerosis. Aliran darah yang normal menyebabkan ikatan antar sel endotel kuat dan membatasi migrasi dan pergerakan sel endotel. Pengaturan ekspresi gen juga bersifat protektif terhadap pembuluh darah. Dengan demikian shear stress secara fisiologis mencegah terlepasnya sel endotel dari jaringan dengan peranan sitoskeleton dalam hal ini molekul adherens junction yakni VE-Cadherin, sebaliknya bila shear stress ini rendah dan berubah-ubah (oscillatory) maka bersifat merusak endotel [7]. Sel endotel memanjang dan berjajar searah dengan shear stress-nya. Perubahan bentuk sel endotel ini dapat terjadi karena interaksi individu sel dengan sel disebelahnya melalui cell to cell junction. Pada penderita infark miokard banyak ditemukan sel endotel terlepas (endothelial detachment) [8]. Terlepasnya sel endotel ini dapat terjadi karena terlepasnya ikatan antar sel endotel yang diperankan oleh VE-Cadherin [9].

Dengan demikian penelitian ini dilakukan untuk mengetahui peran VE-cadherin pada lepasnya sel endotel dalam kultur sel endotel umbilikus (HUVECs) yang dipapar fluid shear stress. Lepasnya sel endotel dari membran dasar pada penelitian ini diukur dari besarnya densitas sel endotel sebelum dan sesudah shear stress dan skor gambaran struktur VE-Cadherin.

\section{METODE PENELITIAN}

\section{Kultur Sel Endotel}

Penelitian ini bersifat eksperimental yang dilakukan secara in vitro. Vena umbilikus yang telah dibersihkan dengan menggunakan larutan phosphat buffer saline-A (PBS-A) diisolasi secara enzimatis dengan collagenase tipe II yang dilarutkan dalam medium serum free yang terdiri atas medium M199 (Gibco), $100 \mu / \mathrm{ml}$ Penicillin dan $100 \mu / \mathrm{ml}$ Streptomycin (Sigma), $21 \mathrm{mM} / \mathrm{ml}$ larutan Natrium bicarbonat-phenol red, $2 \mathrm{mM}$ 
glutamine, sel diinkubasi selama 7 menit dan dibilas dengan $10 \mathrm{ml}$ larutan PBS-A. Larutan yang mengandung sel endotel disentrifugasi dengan kecepatan $1000 \mathrm{rpm}$ selama 8 menit sehingga diperoleh pellet (sel endotel). Sel endotel ditanam di atas obyek glass dalam plate kultur dengan 6 sumur. Setelah sel endotel terbentuk monolayer dan konfluen (34 hari), dilakukan pemberian d-glukosa sebanyak $22 \mathrm{mM}$ selama 7 hari. Penggantian medium dilakukan 2 hari sekali.

Fluid Shear stress

Perlakuan fluid shear stress dipergunakan alat cone and plate, sebagaimana penelitian [2]. Skema bagan cone and plate dapat dilihat pada Gambar 1. Shear stress sebesar $10 \mathrm{dyne} / \mathrm{cm}^{2}$, lama tereksposnya endotel mengalami shear stress dengan variasi waktu 5 menit, 8 menit, 12 menit dan 15 menit. Dasar pemilihan besarnya shear stress adalah dari penelitian sebelumnya yang menganalisis produksi NO, dimana terdapat hasil yang siknifikan pada 10 dyne $/ \mathrm{cm}^{2}$ dibanding kontrol selama 5 dan 15 menit. Dengan demikian dikembangkan variasi waktu shear stress antara 5 dan 15 menit untuk mengetahui pengaruhnya terhadap perubahan morfologi, densitas sel endotel dan struktur VE-Cadherin. Pengamatan dan Pengukuran Densitas Sel Endotel

Pengamatan morfologi sel endotel dilakukan dengan menggunakan mikroskop inverted pada sebelum dan sesudah shear stress. Tingkat kepadatan sel dihitung secara manual dibawah mikroskop inverted pada hari ketujuh perlakuan glukosa $22 \mathrm{mM}$. Penghitungan dilakukan pada jumlah sel endotel yang hidup berdasarkan kriteria dari McGrawth et.al. Hasil penelitian diuji dengan uji Beda Nyata Terkecil (BNT) dengan tingkat signifikansi 0,05.

Imunohistokimia

Teknik imunohistokimia uintuk mengamati struktur VE-Cadherin berdasarkan modifikasi prosedur yang dilakukan oleh Buchwalow and Bocker (2010). Sel endotel yang ditumbuhkan pada cover slip dicuci dengan PBS steril $\mathrm{pH}$ 7,4 sebanyak 3 kali, fiksasi metanol selama 58 menit. Kemudian cuci dengan PBS steril, masing-masing well $2 \mathrm{ml}$ inkubasi selama 5 menit. Kemudian dicuci dengan PBS steril 3 kali. Inkubasi $\mathrm{H}_{2} \mathrm{O}_{2} 3 \%$ masing masing well $1 \mathrm{ml}$ selama 10 menit. Kemudian cuci dengan PBS steril, masing-masing well $2 \mathrm{ml}$ selama 5 menit, dicuci 3 kali. Kemudian inkubasi FBS $5 \%$ sejumlah $1 \mathrm{ml}$ tiap well selama 1 jam. Inkubasi dengan antibodi primer VECadherin/Filamen aktin mouse monoclonal IgG1 1:100 sejumlah $1 \mathrm{ml}$ tiap well semalam. Cuci dengan PBS steril, masing-masing well 2 $\mathrm{ml}$ selama 5 menit, dicuci 3 kali. Inkubasi dengan Gout Anti Mouse IgG B Human Adsorbed Biotin Conjugated 1:200 selama 1 jam, sebanyak $1 \mathrm{ml}$ tiap well. Cuci dengan PBS steril, masing-masing well $2 \mathrm{ml}$ selama 5 menit, dicuci 3 kali. Inkubasi SA-HRP 1:500, $1 \mathrm{ml}$ tiap well selama 40 menit. Cuci dengan PBS steril, masing-masing well $2 \mathrm{ml}$ selama 5 
menit, dicuci 3 kali. Inkubasi DAB (Diamino Benzidine) 1 butir untuk $10 \mathrm{ml}$ buffer DAB sebanyak $1 \mathrm{ml}$ tiap well selama 20 menit. Cuci dengan PBS steril, masing-masing well $2 \mathrm{ml}$ selama 5 menit, dicuci 3 kali. Cuci dengan aquadest steril sebanyak $2 \mathrm{ml}$ tiap well selama 5 menit. Counterstain dengan Meyer Hematoxylen sebanyak $1 \mathrm{ml}$ tiap well selama 10 menit. Cuci dengan air kran. Slide dipasang pada dek glass, ditutup dengan cover slip.

Skoring struktur VE-Cadherin

Pengamatan VE-Cadherin dilakukan menggunakan sistem skoring dengan pertimbangan mikroskop yang digunakan adalah mikroskop binokuler. Tiap 100 sel endotel dihitung skor struktur VE-Cadherin yang menyerupai benang-benang yang menghubungkan antar sel endotel pada bagian perifer. Penghitungan skor ini dilakukan pengulangan sebanyak tiga kali. Skor 2 diberikan bila pada pengamatan didapatkan $50 \%$ atau lebih struktur VE-Cadherin pada sel endotel utuh. Skor 1 diberikan bila pada pengamatan didapatkan $50 \%$ atau lebih struktur VE-Cadherin pada sel endotel terputus pada area sekitar pertengahan. Sebaliknya skor 0 diberikan bila pada pengamatan didapatkan $50 \%$ atau lebih struktur VE-Cadherin pada sel endotel terputus sama sekali. Analisis data menggunakan Uji $\mathrm{t}$ dan uji pembandingan berganda Tukey HSD baik pada penghitungan skor struktur VE-Cadherin maupun densitas sel endotel.

\section{HASIL PENELITIAN}

\section{Morfologi Sel Endotel dengan paparan}

\section{Glukosa Tinggi dan Shear Stress}

Sel endotel berubah menjadi berkerut (shrinked) akibat paparan glukosa $22 \mathrm{mM}$ selama 7 hari lebih. Perlakuan shear stress selama lima menit nampak sekali sel endotel dominan mengalami shrinked. Begitu juga pada menit kedelapan dan keduabelas. Pada menit kelimabelas nampak densitas sel menurun, terlihat ruangan kosong diantara sel endotel (gambar tidak kami publikasikan).

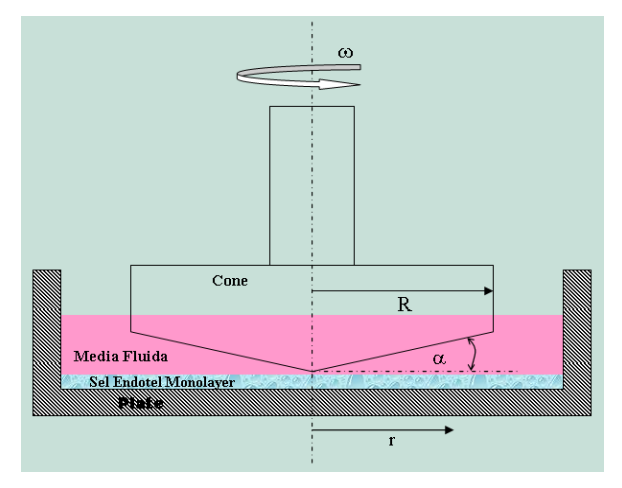

Gambar 1. Peralatan Shear Stress dengan ConePlate [10]

Vascular Endothelial Cadherin (VECadherin) pada pulasan imunohistokimia terlihat berupa gambaran benang-benang yang menghubungkan antar membran sel. Pada kondisi normal benang-benang penghubung ini utuh. Adanya paparan glukosa tinggi dan shear stress menyebabkan terputusnya benang-benang tersebut. Setelah dilakukan pulasan imunohistokimia VE-Cadherin kemudian dilakukan penghitungan skor pada tiap 100 sel endotel dengan pengulangan sebanyak tiga kali. Hasil uji BNT menunjukkan paparan glukosa $22 \mathrm{mM}$ selama 7 hari dan shear stress 5 menit signifikan 
menurunkan skor VE-Cadherin. Sedangkan pada variabel shear stress 8,12 dan 15 menit terdapat penurunan namun tidak signifikan.

Tabel 1. Skor VE-Cadherin pada paparan glukosa $5 \mathrm{mM} / \mathrm{L}$ dan $22 \mathrm{mM} / \mathrm{L}$ dan shear stress

\begin{tabular}{ccc}
\hline $\begin{array}{c}\text { Kadar } \\
\text { Glukosa } \\
(\mathrm{mM} / \mathrm{L})\end{array}$ & $\begin{array}{c}\text { Lama } \\
\text { shear } \\
\text { stress }\end{array}$ & Skor VE-Cadherin \\
\hline & 0 & $73,67 \pm 5,03$ \\
& 5 & $72,67 \pm 3,51^{*}$ \\
5 & 8 & $55 \pm 8,66^{*}$ \\
& 12 & $52,67 \pm 4,93^{*}$ \\
& 15 & $52 \pm 3,46^{*}$ \\
\hline & 0 & $55,67 \pm 13,57$ \\
& 5 & $54,67 \pm 3,05^{*}$ \\
& 8 & $35,67 \pm 3,78^{*}$ \\
& 12 & $33,67 \pm 13,57^{*}$ \\
& 15 & $32,67 \pm 13,86^{*}$ \\
\hline
\end{tabular}

Ket: data $=$ rerata $\pm \mathrm{SD}, \mathrm{n}=$ masing-masing $3, p<$ 0,05

\section{Densitas Sel Endotel pada Paparan Glukosa Tinggi dan Fluid Shear stress}

Pada paparan glukosa $22 \mathrm{mM}$ selama 7 hari dan shear stress dapat menurunkan densitas sel endotel namun tidak ada perbedaan yang nyata. Sebagaimana tampak pada grafik Gambar 2. Hasil pengamatan menunjukkan penurunan densitas sel endotel pada well kultur $6,85 \mathrm{~cm}^{2}$ oleh paparan glukosa $22 \mathrm{mM}$ selama 7 hari dan fluid shear stress secara signifikan terutama pada menit kedelapan dan keduabela sebagaimana ini dapat dilihat pada Tabel 2.

Korelasi perubahan Skor VE-Cadherin dengan densitas sel endotel menunjukkan hasil yang signifikan, dimana penurunan baik pada skor VE-Cadherin maupun densitas sel endotel saling berpengaruh satu sama lain.

\section{Densitas Sel Endotel pada Pap Glukosa $22 \mathrm{mM}$ selama $7 \mathrm{~h}$}

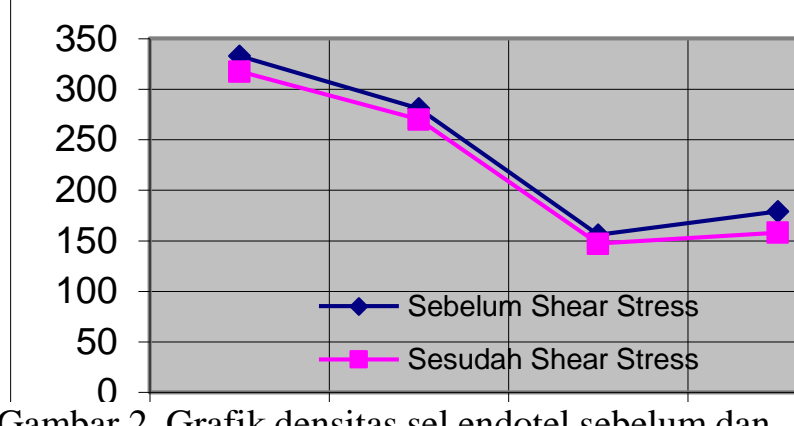

Gambar 2. Grafik densitas sel endotel sebelum dan sesudah shear stress pada paparan glukosa $22 \mathrm{mM}$ selama 7 hari.

Tabel 2 Rata rata densitas sel $/ \mathrm{mm}^{2}$ pada paparan glukosa $22 \mathrm{mM}$ dan fluid shear stress

\begin{tabular}{|c|c|c|c|}
\hline \multirow{2}{*}{ Pasangan } & \multirow{2}{*}{ Perlakuan } & \multicolumn{2}{|c|}{$\begin{array}{c}\text { Densitas } \\
\left(\mathrm{sel} / / 7,5 \times 10^{-4} \mathrm{~mm}^{2}\right)\end{array}$} \\
\hline & & Sebelum & Sesudah \\
\hline 1 & $\begin{array}{c}\text { Shear stress } 5 \\
\text { mnt }\end{array}$ & $375 \pm 85$ & $306 \pm 57$ \\
\hline 2 & $\begin{array}{c}\text { Shear stress } 8 \\
\text { mnt }\end{array}$ & $204 \pm 76$ & $156 \pm 28 *$ \\
\hline 3 & $\begin{array}{l}\text { Shear stress } \\
12 \mathrm{mnt}\end{array}$ & $515 \pm 91$ & $386 \pm 50 *$ \\
\hline 4 & $\begin{array}{c}\text { Shear stress } \\
15 \mathrm{mnt}\end{array}$ & $357 \pm 51$ & $255 \pm 18$ \\
\hline
\end{tabular}

Tabel 3. Korelasi skor VE-Cadherin dan densitas sel endotel pada perlakuan glukosa 22 selama 7 hari

\begin{tabular}{ccc}
\hline $\begin{array}{c}\text { Korelasi sesudah } \\
\text { shear stress }\end{array}$ & $\begin{array}{c}\text { Skor VE- } \\
\text { Cadherin }\end{array}$ & $\begin{array}{c}\text { Densitas sel } \\
\text { endotel }\end{array}$ \\
\hline Skor VE- & 1.000 & $.671^{*}$ \\
Cadherin & & \\
Densitas sel & $.671^{*}$ & 1.000 \\
endotel & & \\
\hline
\end{tabular}

* korelasi signifikan pada tingkat 0.05

\section{DISKUSI}

Perubahan bentuk sel endotel oleh karena paparan glukosa tinggi (22 mM/L) selama 7 hari menjadi bulat, berkerut 
(shrinked) dan perbandingan inti dengan sitoplasma menjadi mengecil menunjukkan adanya tanda-tanda apoptosis pada sel akibat stres oksidatif. Inti sel membesar sehingga perbandingan inti dan sitoplasma mengecil merupakan tanda-tanda sel endotel mengalami apoptosis [11]. Perubahan morfologi ini menegaskan kembali beberapa penelitian sebelumnya bahwa sel endotel terpapar glukosa tinggi $(22 \mathrm{mM} / \mathrm{L})$ selama 7 hari mengakibatkan apoptosis pada sel endotel [10, 12]. Permatasari (2003). Perubahan bentuk sel endotel ini diduga berkaitan dengan peningkatan kalsium sitosol, peningkatan $\mathrm{H}_{2} \mathrm{O}_{2}$ dan penurunan tingkat respirasi mitokondria Peningkatan ion kalsium akan memicu aktivitas MLCK sehingga sel mengalami kontraksi dan sel membulat. Selain itu $\mathrm{Ca}^{2+}$ yang tinggi dapat menyebabkan disosiasi filamen mikro actin dari $\alpha$-actinin dan mendeplesi protein tempat terikat actin sehingga jangkar dari sitoskeleton hilang yang diikuti membran sel berkerut (Halliwell \& Gutteridge, 1999).

Sedangkan perubahan bentuk sel endotel karena perlakuan shear stress menegaskan kembali temuan beberapa penelitian sebelumnya yaitu shear stress menyebabkan sel endotel mengalami perubahan struktural dari bentuk kuboidal (cobblestone) menjadi bentuk poligonal (memanjang) dan alur susunannya searah dengan alur shear stress-nya [13]. Perubahan morfologikal ini merupakan adaptasi sel endotel terhadap adanya fluktuasi shear stress. Pada penelitian ini paparan shear stress 5 menit mulai nampak beberapa sel endotel berubah bentuk menjadi poligonal (memanjang). Pada shear stress 8 menit semakin bertambah jumlah sel endotel yang mengalami perubahan bentuk menjadi poligonal. Pada shear stress 12 menit hampir semua sel endotel mengalami perubahan bentuk memanjang dan berjajar sesuai arah shear stress. Pada shear stress 15 menit perubahan bentuk sel endotel tidak berbeda dengan shear stress 12 menit. Secomb dan Pries (2001) dalam penelitian menjelaskan peranan attachment point of endothelial surface layer dalam mentransmisikan stimulasi shear stress pada membran sel endotel [14]. Penelitian sebelumnya menjelaskan mengenai hipotesa tentang shear stress bisa mempengaruhi morfologi sel endotel melalui kontak adesi fokal pada permukaan endotel yang kemudian ditransmisikan melalui sitoskeleton endotel dengan melibatkan jaringan mikrotubul dan mikrofilamen [15]. Dengan demikian terjadi peningkatan kalsium sitosol dan fosforilasi protein tirosin dimana keduanya berperan dalam reorganisasi sitoskeleton dan adesi fokal pada konfigurasi baru sebagai adaptasi dengan adanya shear stress. Perubahan morfologi dan alur sel endotel dan induksi filamen aktin dengan adanya shear stress tergantung pada kadar kalsium, aktivitas tirosin kinase dan keberadaan mikrotubul dan tidak tergantung 
pada protein kinase $\mathrm{C}$ dan filamen intermediet. Perubahan morfologi dan alur sel endotel pada kultur statik diketahui mulai terjadi pada paparan shear stress 7 dyne $/ \mathrm{cm}^{2}$ yang disebabkan oleh reorganisasi sitoskeletal [12].

Pengaruh Paparan Glukosa Tinggi dan Fluid Shear Stress terhadap Perubahan Struktur VE-Cadherin

Paparan glukosa tinggi (22 $\mathrm{mM} / \mathrm{L})$ selama 7 hari menyebabkan penurunan skor VE-Cadherin dengan pengaruh yang nyata $(\mathrm{p}$ 0,000). Paparan glukosa tinggi pada sel endotel menginduksi pembentukan ROS (Reactive Oxigen Species) yang dapat mengaktivasi jalur seluler sehingga memicu terjadinya stres oksidatif yang disebabkan oleh produksi oksidan yang berlebihan. Dampak langsung dari meningkatnya stres oksidatif ini terjadi pada sel endotel sehingga pada adesi antar sel endotel terutama VE-Cadherin terjadi kerusakan. Penelitian ini menunjukkan adanya penurunan skor VE-Cadherin pada paparan glukosa $22 \mathrm{mM} / \mathrm{L}$ selama 7 hari. Terbukti bahwa adanya stres oksidatif menyebabkan terjadinya remodelling struktur VE-Cadherin. ROS mempengaruhi adherence junction termasuk VE-Cadherin melalui modifikasi oksidatif langsung. ROS mendeplesi ATP seluler. Adanya stres oksidatif menyebabkan penurunan secara cepat tingkat ATP seluler karena inaktivasi glikolitik dan inaktivasi jalur fosforilasi ADP pada mitokondria. Penurunan ATP seluler karena oksidan dapat disertai oleh disrupsi filamen aktin [16]. Beberapa kajian mengenai pengaruh radikal bebas/ROS pada sel endotel pembuluh darah menunjukkan bahwa $\mathrm{H}_{2} \mathrm{O}_{2}$ dapat menghambat sintesis ATP. Hambatan tersebut dapat terjadi pada proses glikolisis maupun siklus Krebs. $\mathrm{H}_{2} \mathrm{O}_{2}$ dapat mengganggu sintesa ATP di sitoplasma dengan menurunkan glikolisis melalui hambatannya pada aktivitas GADPH. $\mathrm{H}_{2} \mathrm{O}_{2}$ dapat mengoksidasi gugus sulfhidril ensim tersebut. Penelitian sebelumnya membuktikan adanya penurunan tingkat respirasi mitokondria karena pengaruh paparan glukosa tinggi [17].

Mekanisme terlepasnya sel endotel belum banyak diketahui. Beberapa penyebab terlepasnya sel endotel dari membran dasar yakni adanya stress oksidatif dan proses inflamasi. Selain itu juga dipengaruhi oleh struktur perlekatan antar sel endotel dan ikatan dengan matriks ekstraseluler yang diperantarai oleh VE-cadherin, fibronektin, vitronektin dan integrin adalah penting dalam kelangsungan hidup sel endotel [9]. Pernyataan tersebut mendukung hasil penelitian ini dimana skor VE-Cadherin menurun setelah perlakuan shear stress. VE-Cadherin sebagai glikoprotein transmembran menghubungkan secara fisik antar membran sel endotel. VE-Cadherin terbentang dari bagian sitoplasmik yang terikat dengan protein sitoskeletal ke domain ekstraseluler. Pada bagian intraseluler VECadherin berikatan dengan catenin $(\alpha-, \beta-, \gamma-$ catenin atau plakoglobin) yang kemudian berikatan dengan $\alpha$-actinin yang dapat 
menghubungkan dengan mikrofilamen aktin sehingga menstabilisasi hubungan tersebut (Dejana, 1999). Sel endotel membentuk kompleks junction dengan sel endotel disebelahnya melalui adherens junction, tight junction dan gap junction. Terbentuknya komplek adherens junction merupakan prasyarat terbentuknya kompleks junctional yang lain. Sebaliknya terputusnya kompleks rangkaian ini menyebabkan perubahan bentuk sel, reorientasi, migrasi dan proliferasi yang berkaitan dengan perbaikan kerusakan pembuluh darah karena terlepasnya endotel. Perubahan adherens junction terutama VEcadherin dapat terjadi karena shear stress dan kemudian mengalami adaptasi berupa reorganisasi aktin sitoskeleton dan VEcadherin. Oleh karenanya shear stress menyebabkan redistribusi F-aktin dan VEcadherin yang terlihat menyolok pada kultur statik. Sedangkan bila tidak ada shear stress gambaran tersebut tidak nampak [18]. Penelitian ini menunjukkan bahwa dengan adanya shear stress menyebabkan perubahan struktur VE-Cadherin sehingga terjadi penurunan skor VE-Cadherin. Penurunan skor ini bermakna pada paparan shear stress lebih dari lima menit. (8, 12 dan 15 menit) Perlu ditingkatkan lagi waktu paparan shear stress sehingga perubahan struktur VE-Cadherin nampak bermakna. Demikian pula besarnya shear stress ditambah variabelnya tidak hanya pada 10 dyne $/ \mathrm{cm}^{2}$ saja. Namun pertimbangan dipilihnya 10 dyne $/ \mathrm{cm}^{2}$ didasarkan pada penelitian sebelumnya bahwa tidak terdapat perbedaan yang bermakna pada produksi Nitric Oxide (NO) antara 6 dyne $/ \mathrm{cm}^{2}$ dengan 10 dyne $/ \mathrm{cm}^{2}$ [19]. Pada 10 dyne $/ \mathrm{cm}^{2}$ terdapat perbedaan signifikan terutama pada variabel waktu 5 dan 15 menit. Peningkatan paparan shear stress sampai 30 menit tidak terdapat perbedaan yang bermakna. Dengan demikian dipilih variabel waktu antara 5 dan 15 menit untuk mengetahui perbedaan antara waktu tersebut. Penurunan skor VE-Cadherin mengindikasikan adanya kerusakan struktur VE-Cadherin yang disebabkan oleh shear stress. Perubahan struktur VE-Cadherin diduga mempengaruhi mobilitas hubungan sel dengan sel melalui perantaraan aktin sitoskeleton. Sehingga perubahan ini berpengaruh pula terhadap morfologi sel endotel yang terjadi pada proses pertumbuhan sel menjadi konfluen dan perbaikan kerusakan pada kultur sel endotel monolayer [18]. Sejalan dengan pernyataan tersebut, pada penelitian ini menunjukkan perubahan morfologi sel endotel karena shear stress disertai adanya penurunan skor VE-Cadherin. Perubahan morfologi dapat terjadi pada kerusakan sebagian rangkaian VE-Cadherin. VE-Cadherin merupakan bagian yang tidak stabil terhadap shear stress dibanding struktur lain seperti $\alpha$-catenin, $\beta$-catenin dan plakoglobin. Terutama plakoglobin merupakan struktur utama adherence junction yang menstabilisasi sel endotel terhadap shear stress yang lama [18]. Oleh karenanya pada 
penelitian ini tidak terdapat perbedaan skor VE-Cadherin dengan perlakuan shear stress lebih dari 8 menit. Kemungkinan terdapat mekanisme stabilisasi hubungan antar sel endotel melalui struktur lain penyusun adherence junction seperti $\alpha$-catenin, $\beta$ catenin dan plakoglobin.

Dengan demikian dapat ditarik kesimpulan bahwa paparan glukosa tinggi dan shear stress dapat menyebabkan perubahan struktur VE-Cadherin sehingga terjadi kerusakan. VE-Cadherin juga memberikan kontribusi terhadap regulasi permeabilitas yang dilakukan oleh protein junction [20]. dalam penelitiannya melaporkan terjadi peningkatan adsorbansi albumin pada HUVECs yang dipapar glukosa $22 \mathrm{mM}$ selama 7 hari. Hal ini menunjukkan terjadinya kebocoran dimana albumin bisa melewati membran filter, dan ini menandakan terjadi gangguan permeabilitas pada HUVECs yang dipapar glukosa tinggi [21].

Efek Shear Stress dan Glukosa Tinggi terhadap Perubahan Densitas Sel Endotel

Densitas sel endotel pada kondisi paparan glukosa normal menunjukkan penurunan densitas setelah perlakuan shear stress. Perubahan densitas sel endotel sesudah perlakuan shear stress menunjukkan perbedaan yang nyata setelah dilakukan analisis uji t berpasangan. Pada shear stress 8 menit dan 12 menit menunjukkan perbedaan yang paling nyata pada penurunan densitas sel endotel sesudah shear stress dibandingkan variabel waktu shear stress yang lain ( $p 0,020$ pada shear stress 8 menit dan 0,000 pada shear stress 12 menit). Penurunan densitas sel endotel karena paparan shear stress menunjukkan bahwa sel endotel mengalami apoptosis dan terlepas dari membran dasar. Shear stress menyebabkan sel endotel terlepas dari dasar diduga karena adanya perubahan struktur sitoskeleton, disrupsi filamen aktin dan terputusnya rangkaian VE-Cadherin. (Malek and Izumo, 1996) Adanya stimulasi mekanikal menyebabkan adesi sel dengan sel teregang. (Noria,et.al, 1999) Shear stress menyebabkan mobilitas hubungan sel dengan sel meningkat. Peningkatan mobilitas sel endotel ini terjadi karena ada interaksi komplek protein yang membentuk adherence junction yakni VE-Cadherin dengan struktur sitoskeleton. Proses adaptasi ini sejalan dengan fakta adanya perubahan morfologi sel endotel karena stimulasi shear stress. Dimmeler (2000) menjelaskan adanya pengaruh shear stress terhadap siklus sel endotel. Pada pembuluh darah percabangan, daerah kurvatura dan bifurkasi dimana shear stressnya mengalami penurunan $\left(<10\right.$ dyne $\left./ \mathrm{cm}^{2}\right)$ dan alirannya turbulen ditemukan sel endotel yang terlepas. Terlepasnya sel endotel ini nantinya memberi sinyal untuk meningkatkan aktivitas siklus sel dan meningkatnya proliferasi sel endotel. Dengan demikian shear stress yang rendah dan aliran yang turbulen memberi dampak yang sifatnya pro-apoptotik pada sel endotel. Stimulasi shear stress ini 
mengaktifkan caspase cascade pada sel endotel melalui hormon endostatin, angiostatin dan trombospondin. Beberapa hormon ini mengaktifkan sinyal oleh tirosin kinase yang menyebabkan terjadinya apoptosis melalui penurunan protein antiapoptosis seperti Bcl-2 dan Bcl-XL [22].

Sedangkan pada perlakuan glukosa 22 $\mathrm{mM} / \mathrm{L}$ selama 7 hari terjadi penurunan densitas sel endotel bila dibandingkan dengan perlakuan glukosa normal ( $5 \mathrm{mM} / \mathrm{L})$ selama 7 hari. Densitas sel endotel baik pada paparan glukosa $5 \mathrm{mM} / \mathrm{L}$ maupun $22 \mathrm{mM} / \mathrm{L}$ selama 7 hari menunjukkan perbedaan yang nyata. Analisis uji t tidak berpasangan menunjukkan nilai p 0,004 yang berarti terdapat perbedaan yang nyata pada penurunan densitas sel endotel tanpa perlakuan shear stress pada paparan glukosa $22 \mathrm{mM}$ selama 7 hari. Data ini menegaskan kembali penelitian sebelumnya bahwa terjadi penurunan densitas sel endotel oleh paparan glukosa $22 \mathrm{mM} / \mathrm{L}$ selama 7 hari dibanding glukosa $5 \mathrm{mM}[23,24,25,26,27]$.. juga membuktikan bahwa pada kultur HUVECs dengan kondisi hiperglikemi terjadi penurunan jumlah sel yang cukup tajam pada hari ketiga. Penurunan ini terjadi karena stres oksidatif menyebabkan gangguan replikasi sel endotel sekaligus menginduksi terjadinya apoptosis [23, 24, 25, 26, 27]. Sedangkan pada densitas sel endotel sesudah shear stress menunjukkan perbedaan yang nyata baik pada paparan glukosa $22 \mathrm{mM} / \mathrm{L}$ (p 0,031). Hal ini menunjukkan bahwa dengan adanya paparan glukosa tinggi dan shear stress menyebabkan penurunan densitas sel endotel. Stres oksidatif menghasilkan radikal bebas yang berpotensial menginduksi caspase cascade dari sel endotel sehingga terjadi apoptosis. Secara mekanis dijelaskan bahwa adanya shear stress diduga menyebabkan penurunkan produksi NO dan mempengaruhi peranan scavenger sel endotel terhadap produksi radikal oksigen dan menyebabkan stres oksidatif. (Dimmeler, 2000) Pada penelitian ini penurunan densitas pengaruhnya nyata pada shear stress 5 menit hingga 8 menit, sedangkan pada variabel selanjutnya tidak terdapat pengaruh yang nyata. Penurunan densitas sel endotel setelah perlakuan shear stress $10 \mathrm{dyne} / \mathrm{cm}^{2}$ berkaitan dengan terlepasnya sel endotel dari dasar (endothelial detachment) yang berhubungan dengan fungsi VE-Cadherin. Pada perlakuan shear stress menit keduabelas tidak didapatkan penurunan densitas sel endotel yang disebabkan oleh kemampuannya beradaptasi dengan adanya stimulasi gaya hemodinamik. Shear stress mempengaruhi sinyal cascade pada beberapa faktor spesifik yang berperan terhadap keberadaan endotel agar tetap hidup atau disebut juga endothelial-specific survival factors (Dimmeler, 2000).

Pada hasil analisis persamaan simultan tentang hubungan skor VE-Cadherin dan densitas sel endotel dengan paparan glukosa tinggi (22 $\mathrm{mM} / \mathrm{L})$ dan shear stress dapat disimpulkan bahwa pemberian glukosa 22 $\mathrm{mM} / \mathrm{L}$ selama 7 hari dapat menurunkan secara 
siknifikan skor VE-Cadherin ( $p$ 0.000) dan densitas sel tanpa perlakuan shear stress ( $\mathrm{p}$ $0.005)$ dan dengan perlakuan shear stress ( $\mathrm{p}$ 0.035). Demikian juga pemberian shear stress $(5,8,12,15$ menit) dapat menurunkan skor VECadherin secara nyata ( $p$ 0.005). Jadi paparan glukosa tinggi $(22 \mathrm{mM} / \mathrm{L})$ selama 7 hari memberikan kontribusi yang lebih besar dalam menurunkan skor VE-Cadherin dan densitas sel dengan perlakuan shear stress.

\section{KESIMPULAN}

Paparan Glukosa $22 \mathrm{mM} / \mathrm{L}$ dan shear stress menyebabkan kerusakan struktur VECadherin sehingga benang-benang penghubung antar sel endotel terputus. Terputusnya struktur cell to cell junction ini memicu sel endotel terlepas dari membran dasar sehingga densitas sel endotel menurun.

Dengan demikian paparan glukosa tinggi dan fluid shear stress tersebut menyebabkan peningkatan apoptosis dan nekrosis sel endotel.

\section{UCAPAN TERIMAKASIH}

Terimakasih kepada Direktorat Jenderal Pendidikan Tinggi Departemen Pendidikan Nasional yang telah membiayai penelitian ini sebagaimana tercantum pada surat perjanjian pelaksanaan Penelitian Dosen Muda nomor 099/SP2H/PP/DP2M/IV/09 tertanggal 6 April 2009

\section{REFERENSI}

1. Organization, W.H., Global health risks: mortality and burden of disease attributable to selected major risks. 2009: World Health Organization.

2. Montezano, A.C. and R.M. Touyz, Molecular mechanisms of hypertension-reactive oxygen species and antioxidants: a basic science update for the clinician. Canadian Journal of Cardiology, 2012. 28(3): p. 288-295.

3. Falk, E., Pathogenesis of atherosclerosis. Journal of the American College of Cardiology, 2006. 47(8 Supplement): p. C7-C12.

4. Qiu, Y. and J.M. Tarbell, Interaction between wall shear stress and circumferential strain affects endothelial cell biochemical production. Journal of vascular research, 2000. 37(3): p. 147-157.

5. Gimbrone Jr, M.A. and G. GarcíaCardeña, Endothelial cell dysfunction and the pathobiology of atherosclerosis. Circulation research, 2016. 118(4): p. 620-636.

6. Cucullo, L., et al., The role of shear stress in Blood-Brain Barrier endothelial physiology. BMC neuroscience, 2011. 12(1): p. 1-15.

7. Dolan, J.M., J. Kolega, and H. Meng, High wall shear stress and spatial gradients in vascular pathology: a review. Annals of biomedical engineering, 2013. 41(7): p. 14111427.

8. Davies, P.F., Hemodynamic shear stress and the endothelium in cardiovascular pathophysiology. Nature clinical practice Cardiovascular medicine, 2009. 6(1): p. 16-26.

9. Woywodt, A., et al., Circulating endothelial cells: life, death, detachment and repair of the endothelial cell layer. Nephrology Dialysis Transplantation, 2002. 17(10): p. 1728-1730.

10. Sulistyowati, E., N. Permatasari, and M.A. Widodo, Combined effects of shear stress and glucose on the 
morphology, actin filaments, and VEcadherin of endothelial cells in vitro. IJC Heart \& Vasculature, 2017. 15: p. 31-35.

11. Alberts, B., et al., The self-assembly and dynamic structure of cytoskeletal filaments, in Molecular Biology of the Cell. 4th edition. 2002, Garland Science.

12. Sargowo, D., et al., Dynamic Interaction Between Organellas In the Management of Cytosolic Calcium Huvecs Exposed to $22 \mathrm{mM}$ Glucose With Different Period Exposure. Indonesian Journal of Cardiology, 2007: p. 404-410.

13. Elhadj, S., Chronic shear stress effects on endothelial cell response. 2001, Virginia Tech.

14. Pries, A.R., B. Reglin, and T.W. Secomb, Structural adaptation of vascular networks: role of the pressure response. Hypertension, 2001. 38(6): p. 1476-1479.

15. Baharoglu, M.I., et al., Aneurysm inflow-angle as a discriminant for rupture in sidewall cerebral aneurysms: morphometric and computational fluid dynamic analysis. Stroke, 2010. 41(7): p. 1423-1430.

16. Lum, H. and K.A. Roebuck, Oxidant stress and endothelial cell dysfunction. American Journal of Physiology-Cell Physiology, 2001. 280(4): p. C719C741.

17. Kim, W.-H., et al., Exposure to chronic high glucose induces $\beta$-cell apoptosis through decreased interaction of glucokinase with mitochondria: downregulation of glucokinase in pancreatic $\beta$-cells. Diabetes, 2005. 54(9): p. 2602-2611.

18. Noria, S., et al., Transient and steadystate effects of shear stress on endothelial cell adherens junctions. Circulation research, 1999. 85(6): p. 504-514.

19. Wahyudi, S. and A. Widodo. Shear Stress Analysis of Synthesis and Nitric Oxide Release from Huvecs Exposed to Supraphysiologic Glucose. in IOP
Conference Series: Materials Science and Engineering. 2019. IOP Publishing.

20. Dejana, E., F. Orsenigo, and M.G. Lampugnani, The role of adherens junctions and VE-cadherin in the control of vascular permeability. Journal of cell science, 2008. 121(13): p. 2115-2122.

21. Dang, L., J.P. Seale, and X. Qu, High glucose-induced human umbilical vein endothelial cell hyperpermeability is dependent on protein kinase $C$ activation and independent of the Ca2+-nitric oxide signalling pathway. Clinical and Experimental Pharmacology and Physiology, 2005. 32(9): p. 771-776.

22. Dong, G., et al., Low shear stress-induced autophagy alleviates cell apoptosis in HUVECs. Molecular Medicine Reports, 2017. 15(5): p. 3076-3082.

23. Nusindrati, 2001. Pengaruh N-Acetyl Cystein terhadap kadar Oksidan $\left(\mathrm{H}_{2} \mathrm{O}_{2}\right)$, Malondilaldehid (MDA) dan antioksidan Superoksid Dismutase (SOD) pada HUVECs yang dipapar glukosa $22 \mathrm{mM}$. Tesis. Program Pasca Sarjana Universitas Brawijaya. Malang

24. Wuryandari, A.,2002. Profil Oksidan dan Antioksidan Hidrogen Peroksida $\left(\mathrm{H}_{2} \mathrm{O}_{2}\right)$, Superoksida Dismutase (SOD) dan Malondilaldehid (MDA) pada sel endotel (HUVECs) yang dipapar glukosa tinggi. Tesis. Program Pasca Sarjana Universitas Brawijaya. Malang.

25. Yanuhar, Uun. 2002. Karakteristik Molekul Adesi Salmonella typhii dan Molekul Reseptor Sel Endotel HUVECs yang Dipapar Glukosa Tinggi. Tesis. Program Pascasarjana Universitas Brawijaya. Malang.

26. Permatasari N., 2003. Perubahan Kadar Ca2+ Sitosol Basal Sel Endotel Pembuluh Darah yang Terpapar Glukosa Kadar Tinggi dan Hubungannya dengan $\mathrm{H} 2 \mathrm{O} 2$ dan lipid Peroksid.Ringkasan Disertasi Program Doktor di Bidang 
Ilmu Kedokteran Program Pasca Sarjana Universitas Airlangga. Surabaya.

27. Nelwan, Cisca H. 2004. Cytoskeleton Actin Filament Imaging in HUVECs Exposed by High Glucose Miracle or Simply Role of Intracellular Calsium. The $3^{\text {rd }}$ Indonesian Biotechnology Conference, Bali. 